\begin{tabular}{lc}
\hline & ANNALES \\
& UNIVERSITATIS MARIAE CURIE-SKŁODOWSKA \\
LOL. V & LEBLIN - POLONIA \\
\hline
\end{tabular}

ISSN: 2451-0491 • e-ISSN: 2543-9340 - CC-BY 4.0 • DOI: 10.17951/en.2020.5.205-223

\title{
Cyprian Kamil Norwid z perspektywy współczesnej szkolnej recepcji i w odbiorze lokalnego środowiska
}

\section{Cyprian Kamil Norwid from the Perspective of Contemporary School Reception and in the Reception of the Local Environment}

\author{
Wioletta Żórawska \\ Towarzystwo Naukowe Płockie. Sekcja Nauk Humanistycznych \\ pl. Narutowicza 8, 09-402 Płock \\ vzuraw@op.pl \\ https://orcid.org/0000-0002-6587-306X
}

\begin{abstract}
The article concerns the school reception of Cyprian Kamil Norwid's work. The project entitled "Bielski Norwid" (2001-2019), realized at the Gymnasium of Cyprian Kamil Norwid in Bielsko in the Mazowieckie Voivodeship is an example of this type of good practice. The study describes the values that result from the interaction of schoolchildren with the work of this poet as the patron of the school. The author also answers the basic question of Polish studies didactics, i.e. how to make students interested in literature and involve them in interdisciplinary activities.
\end{abstract}

Keywords: Cyprian Kamil Norwid; good practice; schoolchildren; patron of the school; literature

\begin{abstract}
Abstrakt. Artykuł dotyczy szkolnej recepcji twórczości Cypriana Kamila Norwida. Projekt pn. „Bielski Norwid” (2001-2019), zrealizowany w Gimnazjum im. Cypriana Kamila Norwida w Bielsku w województwie mazowieckim, jest przykładem tego typu dobrej praktyki. W opracowaniu opisano wartości będące efektem obcowania młodzieży szkolnej z twórczością tego poety jako patrona szkoły. Autorka ponadto odpowiada na podstawowe pytanie dydaktyki polonistycznej, czyli jak zaciekawić uczniów literaturą i zaangażować ich do działań interdyscyplinarnych.
\end{abstract}

Słowa kluczowe: Cyprian Kamil Norwid; dobra praktyka; młodzież szkolna; patron szkoły; literatura 


\section{WPROWADZENIE}

Szkolna recepcja twórczości Cypriana Kamila Norwida to problem badawczy, który mieści się w następujących obszarach: norwidologia, szkolny Norwid, dydaktyka literatury, literaturoznawstwo, historia oświaty - i dotyczy ostatniego stulecia (Źórawska 2016b: 29-60). W dwudziestoleciu międzywojennym twórca Fortepianu Szopena stał się autorem szkolnym, zapisanym w programach nauczania, podręcznikach do literatury i poradnikach metodycznych dla nauczycieli. Współczesne ustalenia norwidologii obejmują wszystkie gatunki twórczości autora Czarnych kwiatów, z przewagą interpretacji liryki (o ich liczebności zob. Cedro i in. 2001). Nie sposób pominąć obecnych osiągnięć edytorskich, które stopniowo przenikają do powszechnej świadomości, ale potrzeba czasu, aby udostępnione zostały także szkolnemu odbiorcy ${ }^{1}$.

W dobie rewolucji komunikacyjnej i stosowania technologii informacyjno-komunikacyjnej (TiK) wciąż zbyt mało mówi się o sięganiu do tych narzędzi, pomocnych w zdobywaniu wiedzy również z zakresu upowszechniania norwidologii w szkole (Żórawska 2016a: 395-402). TiK może wspomóc poznawanie twórczości Norwida, a szczególnie w realizacji lekcji, które wykraczają poza materiał zamieszczony w podręcznikach. Problematyka szkolnego czytania tego autora pojawia się w refleksji naukowej badaczy twórczości Norwida sporadycznie, zazwyczaj z okazji różnych jubileuszy. Brakuje stałego dyskursu środowiska norwidologów i dydaktyków polonistyki dającego odpowiedź na złożone pytanie: Jak w szkole przybliżać twórczość autora Bransoletki w epoce postmodernizmu, dominowania multimediów, obcowania uczniów ze znamiennym dla Internetu hipertekstem, w oddziaływaniu wzorców i wartości kultury masowej? Nadal zniechęcająco działa stereotyp „trudnego autora”, który - powielany przez dziesięciolecia - może negatywnie wpływać na szkolną recepcję i recepcję w ogóle autora Vade-mecum. Głosy dydaktyków literatury powoli zmieniają nastawienie do lektur trudnych, wskazując na argumenty, że pokonywanie etapami barier czytelniczych i doszukiwanie się sensu ukrytego kształci umiejętności interpretacyjne, daje satysfakcję czytelniczą, a nade wszystko prowadzi do pogłębienia refleksji o świecie i o sobie samym.

W kształceniu literackim i regionalnym sprawdza się metoda projektu edukacyjnego (Strawa-Kęsek 2015). Polega ona na opracowaniu przez uczniów

1 Ośrodek badawczy Katolickiego Uniwersytetu Lubelskiego sprawuje pieczę nad wydaniem pierwszej krytycznej edycji Dzieł wszystkich Norwida. Edycja ta składać się będzie z 17 tomów; rozpoczęła się w 2007 roku i jest kontynuowana. Także w tym ośrodku badawczym realizowana jest 7-tomowa edycja pn. Katalog prac plastycznych Norwida pod redakcją Edyty Chlebowskiej. 
tematu w czasie dłuższym niż jedna jednostka lekcyjna. Może być realizowana w okresie tygodnia lub semestru. Charakterystyczna dla projektu edukacyjnego jest duża samodzielność uczniów w realizacji zadania. Praca tą metodą jest niezwykle popularna, ma wiele zalet. W dalszej części artykułu zaprezentowano wybrane przykłady projektów edukacyjnych dotyczących twórczości Norwida, zrealizowanych przez gimnazjalistów w latach 2001-2019. Niestety, metoda projektu edukacyjnego nie jest rozpowszechniona w literaturze przedmiotu dotyczącej szkolnej recepcji twórczości Norwida (Dobiech 2004: 319-322). W publikacji Cyprian Norwid w nowej szkole znalazły się konspekty lekcji dla gimnazjum i liceum. Uwzględniono w nich następujące metody pracy: drama, drzewo decyzyjne, dyskusja, metaplan, praca w grupach, referat, wykład.

Nie trzeba dziś nikogo przekonywać, że teksty Norwida dzięki głębi i uniwersalności zawartych w nich treści stanowią wyzwanie w szkolnej praktyce, nie tylko na lekcjach polskiego. Nauczyciele plastyki mogą zrealizować interesujące zajęcia o Norwidzie jako autorze dzieł literackich i prac plastycznych. Ta artystyczna wszechstronność romantycznego twórcy może zainspirować młodzież do udziału w konkursach związanych z ilustrowaniem jego utworów, a także z tworzeniem fotografii inspirowanych tekstami autora Vade-mecum. Lekcje muzyki zaciekawią młodzież, jeśli nauczyciel zaproponuje poznawanie interpretacji wokalnych liryków romantycznego poety. Uznani artyści na przestrzeni ostatnich dziesięcioleci podejmowali się tworzenia muzyki i interpretacji wokalnej tekstów Norwida. Ich wykonania przeszły do historii i wciąż zyskują uznanie kolejnych pokoleń odbiorców, doczekały się też omówień w publikacjach naukowych. Najbardziej znane i najliczniejsze są kompozycje muzyki do wierszy Norwida oraz ich wokalna interpretacja Czesława Niemena (Bodusz 2009-2010: 101-114; Chlebowski 2009-2010: 77-100; Gajda 2002: 21-27). W powszechnej świadomości również na szkolnym gruncie głęboko utrwaliła się interpretacja wiersza $W$ Weronie do muzyki Andrzeja Kurylewicza w wykonaniu Wandy Warskiej (2003). Młodzież może podjąć próby komponowania muzyki oraz własnych interpretacji tekstów autora Promethidiona, które uzyskają współczesne brzmienie. Nauczyciel informatyki odnajdzie także pole do działania. Można podczas zajęć realizować twórcze i interdyscyplinarne projekty edukacyjne, które zaangażują młodzież np. w tworzenie tablic wirtualnych, komiksów, prezentacji multimedialnych. Podobnie na lekcjach religii ten autor może pojawić się w interesujących interpretacjach.

Wnioski te potwierdza Katarzyna Olszewska, katechetka z wieloletnią praktyką w edukacji młodzieży, w referacie „Aspekt społeczny, religijny i wychowawczy wybranych liryków Cypriana Kamila Norwida w powiązaniu z nauką religii w szkole": 
Twórczość liryczna Norwida daje ogromne możliwości wykorzystania jej w ramach nauczania wielu przedmiotów, w tym także religii, a także wychowania młodego człowieka. Sam Norwid przecież swój światopogląd oparł na kategoriach powiązanych z religią, takich jak:

a) sumienie - „[...] sumienie jest najtajniejszym ośrodkiem i sanktuarium człowieka, gdzie przebywa on sam z Bogiem, którego głos w jego wnętrzu rozbrzmiewa" (Katechizm Kościoła Katolickiego 1994),

b) osoba - rozumiana jako istota wolna i z heroizmem realizująca wartości chrześcijańskie oraz naśladująca Chrystusa,

c) praca - traktowana jako efekt twórczości życiowej człowieka w sferze intelektualno-duchowej i materialnej, przyczyniająca się do postępu cywilizacji.

Związek Norwida z religią, ze sprawami wiary ma swoje silne odzwierciedlenie w jego wierszach. Wszystkie kategorie, na których Norwid opiera swój światopogląd, skupiają się w jednym słowie: Bóg - którego głosem jest sumienie ludzkie, który objawił się w Jezusie Chrystusie, i który stworzył świat, a człowiek w tym stwarzaniu uczestniczy, bo nadal tworzy i udoskonala swoją pracą. Ponadto religijność Norwida, jak dziś stwierdzają znawcy tematu, była mocno ugruntowana, intelektualna, biblijna, w tym bardzo ewangeliczna (Kulczycka i Straszewska 1990: 231). I choć nie zgłębiał on nigdy teologii w sensie dosłownym, to jednak zasługuje na miano teologa, bo w swojej twórczości szeroko rozumianej bardzo dogłębnie przedstawia odwieczne prawdy Boże.

Wykorzystanie poezji Cypriana Kamila Norwida w ramach nauczania religii w starszych klasach szkoły podstawowej i klasach gimnazjalnych może się stać cennym uzupełnieniem wiedzy zdobywanej na lekcjach języka polskiego, mając na uwadze obowiązek wdrażania uczniów do zintegrowanego patrzenia na różne dziedziny wiedzy, umiejętności i postaw (Rozporządzenie Ministra Edukacji Narodowej z dnia 15 lutego 1999 r., Podstawa programowa kształcenia ogólnego dla sześcioletnich szkół podstawowych i gimnazjów). (Norwidpasjonaci.pl 2016f)

W niniejszym artykule ukazuję obraz szkolnej recepcji twórczości Norwida w konkretnym czasie i miejscu. Omawiany tu zespół działań o charakterze edukacyjno-wychowawczym został zrealizowany w latach $2001-2019^{2} \mathrm{w}$ ramach

2 W 2001 roku rozpoczęły się działania wokół C.K. Norwida w ramach obchodów Roku Norwidowskiego z okazji 180. rocznicy urodzin poety, natomiast 31 sierpnia 2019 roku zlikwidowano w wyniku reformy oświaty gimnazjum w Bielsku. 
projektu pn. „Bielski Norwid” ${ }^{3}$ w gimnazjum liczącym do 400 uczniów w środowisku gminy ${ }^{4}$.

Projekt ten jest przykładem dobrej praktyki i może stanowić przyczynek do badań nad szkolnym czytaniem Norwida oraz obecnością tego autora w świadomości społeczeństwa. Celem opracowania jest pokazanie różnych działań zmierzających do spopularyzowania twórczości Norwida wśród młodzieży i w środowisku szkoły oraz rozwiązań metodycznych przydatnych w odczytywaniu twórczości autora Ad leones i odkrywaniu wartości w niej zawartych. Działania dydaktyczno-wychowawcze składające się na wieloletni projekt „Bielski Norwid” przyniosły wiele cennych osiągnięć dydaktyczno-wychowawczych, które domagają się refleksji naukowej. Praca wokół Norwida służyła kształceniu młodzieży ku wartościom, rozwijała ich zainteresowania humanistyczne oraz wyzwalała potrzebę własnej twórczości uczniów.

Rozbudzanie zainteresowania czytelnictwem w ogóle, a w szczególności twórczością Norwida w szkole, jest wyzwaniem dla nauczycieli. Omawiane tu działania edukacyjno-wychowawcze wokół autora Bransoletki w gimnazjum w latach 2001-2019 sprawiły, że stał się on bliski młodzieży intelektualnie, duchowo i emocjonalnie.

Pionierski projekt dydaktyczno-wychowawczy, w którym podkreślano istotę kształcenia świadomości regionalnej, został zrealizowany w Bielsku, na Mazowszu - w miejscu narodzin i młodości autora Fortepianu Szopena. Impulsem do działania była 180. rocznica urodzin Norwida obchodzona w 2001 roku, nazwanym Rokiem Norwidowskim. Opisana tu szkolna recepcja twórczości autora Italiam! Italiam! dzieli się na dwa etapy.

\section{PRACA WOKÓ CYPRIANA KAMILA NORWIDA - KANDYDATA NA PATRONA SZKOŁY (2001-2004)}

Celem była wielopłaszczyznowa kampania promująca poetę jako kandydata na patrona szkoły. Omówienie wskazanych działań popularyzatorskich idei i postaci artysty w szkole może być źródłem inspiracji dla placówek stawiających sobie zadanie promowania kandydata na patrona i pracujących nad kreowaniem wizerunku szkoły.

Działania edukacyjno-wychowawcze zmierzające w etapie pierwszym do osiągnięcia celu głównego, tj. wyboru C.K. Norwida na patrona szkoły, miały

\footnotetext{
3 „Bielski Norwid” to nazwa projektu pochodząca od miejscowości Bielsk w powiecie płockim, w województwie mazowieckim.

4 Miejscowość Bielsk liczy 2,5 tysiąca mieszkańców, a gmina Bielsk - 9 tysięcy.
} 
charakter nie tylko ogólnoszkolny, środowiskowy, lecz także regionalny, a przede wszystkim twórczy i nowatorski.

Ważnym zadaniem zarówno organizacyjnym, jak i edukacyjno-wychowawczym dla szkoły okazało się zorganizowanie jednocześnie dwóch konkursów powiatowych: literackiego pod hasłem "Cyprian Norwid czytany w XXI wieku” oraz plastycznego pt. „Daj obraz słowom Cypriana Norwida”. Uczniowie mieli napisać interpretację wiersza Norwida wybranego spośród tekstów omawianych w gimnazjum lub przemówienie na szkolną akademię z okazji 180. rocznicy urodzin artysty. Wzięło w nich udział ogółem 120 uczestników. Młodzież najchętniej wybierała pisemną interpretację liryki oraz interpretację plastyczną wierszy. Najliczniej reprezentowane były utwory: Moja piosnka [II], W Weronie, Fortepian Szopena. Udział w tych konkursach stanowił wyzwanie dla uczniów, gdyż poszukiwanie i zgłębianie wiedzy o artyście i jego twórczości wykraczało poza program nauczania. Głównym punktem uroczystości był wykład „Dramatyczna aktualność Cypriana Norwida” wygłoszony przez prof. Zbigniewa Sudolskiego (2003) z Uniwersytetu Warszawskiego. Wszyscy uczestnicy konkursów zostali zaproszeni na ogłoszenie wyników do Bielska. Mieli okazję bezpośredniego spotkania z autorytetem nauki oraz badaczem romantyzmu i twórczości Norwida (Norwidpasjonaci.pl 2001).

Kolejne działania edukacyjne mające rozwijać zainteresowanie postacią i twórczością autora Fortepianu Szopena miały charakter lekcji otwartej ${ }^{5}$ i objęły cały zespół klasowy oraz grupę nauczycieli. Następstwem obchodów Roku Norwidowskiego i lekcji otwartej było powołanie do życia szkolnej organizacji jako odpowiedzi na zapotrzebowanie uzdolnionej grupy uczniów piszących wiersze $^{6}$. W programie tej organizacji uwzględniono poznawanie biografii i twórczości Norwida, warsztaty dla uczniów podejmujących literackie próby twórcze oraz prezentowanie ich osiągnięć w środowisku pozaszkolnym. Uczniowie uczestniczyli w programie artystycznym Kawiarenki Literackiej „Pod Dębem” w Domu Broniewskiego w Płocku. Wśród doświadczonych autorów ze Związku Literatów Polskich oraz osób zaangażowanych w życie kulturalne zdobywali doświadczenie w pisaniu i prezentowaniu swoich tekstów, spotykali się też z grupami młodzieży z innych szkół?

5 Przeprowadziła je w 2002 roku mgr Danuta Rychlewska, zasłużona polonistka z Płocka.

6 Stowarzyszenie Młodych Poetów im. Cypriana K. Norwida w Gimnazjum w Bielsku działało od stycznia 2002 roku do końca istnienia gimnazjum, tj. 31 sierpnia 2019 roku.

7 W programie artystycznym Kawiarenki Literackiej „Pod Dębem” w Domu Broniewskiego w Płocku grupa gimnazjalistów ze Stowarzyszenia Młodych Poetów w Bielsku uczestniczyła w 2002 roku siedem razy od lutego do października, z przerwą w wakacje (lipiec-sierpień). 
Nową inicjatywą adresowaną do całej społeczności szkoły i jednocześnie wspierającą rozwój twórczy grupy uzdolnionych uczniów było powołanie Kawiarenki Literackiej Stowarzyszenia Młodych Poetów (SMP) w Bielsku w lutym 2003 roku. Dzięki temu ogółowi młodzieży w gimnazjum umożliwiono kontakt z ciekawymi osobami o dorobku twórczym: literackim i artystycznym $^{8}$. Przedsięwzięcie to gwarantowało budowanie atmosfery wspierającej pisanie wierszy przez szkolną młodzież i przygotowywało grunt do odbioru dzieł Norwida nie tylko w ramach nakreślonych w podstawie programowej. Uczniowie pod kierunkiem polonistki pogłębiali wiedzę o życiu i twórczości poety. Zwracali uwagę na region Mazowsze jako miejsce jego narodzin i wczesnej młodości. Każdorazowo podczas comiesięcznych spotkań recytowali wiersze ulubionego poety - patrona szkolnej organizacji. Byli bardzo zmotywowani do tego działania, gdyż występowali w szkolnej kawiarence przed osobami spoza środowiska, które miały już na swoim koncie dorobek pisarski. Sukcesem dydaktyczno-wychowawczym zakończyła się międzyszkolna współpraca z młodzieżową grupą artystyczną „Będzie Dobrze” z Zespołu Szkół im. Stanisława Staszica w Gąbinie ${ }^{9}$. Do wierszy gimnazjalistów zaprzyjaźniona grupa twórcza skomponowała muzykę. W szkolnej pracowni plastycznej w Bielsku uczniowie wykonywali ilustracje do młodzieńczej twórczości rówieśników. Powstał też program poetycko-muzyczny Piękno na to jest, by zachwycało. Zaprezentowany został podczas IV Gminnego Przeglądu Działalności Szkół zorganizowanego przez Gminny Ośrodek Kultury w Bielsku w czerwcu 2002 roku. Młodzież z bielskiego gimnazjum wystąpiła wraz z zaprzyjaźnioną grupą wokalno-teatralną „Będzie Dobrze” z Gąbina. Uczniowie zaprezentowali własną twórczość, a także promowali wizerunek Norwida - patrona Stowarzyszenia Młodych Poetów. Efektem współpracy członków SMP z Gimnazjum w Bielsku i z Zespołu Szkół w Gąbinie było nagranie płyty kompaktowej w lutym 2003 roku. Zarejestrowano na niej pięć debiutanckich tekstów młodzieży z gimnazjum ${ }^{10}$.

${ }^{8}$ Gośćmi Kawiarenki Literackiej, powołanej do życia w Gimnazjum w Bielsku, byli: Alojzy Balcerzak - artysta malarz z Warszawy, oraz płoccy poeci - ks. Tomasz Opaliński, Lech Franczak, Danuta Rychlewska, Krzysztof Bieńkowski. Uczestnikiem programu Kawiarenki Literackiej był Adam Kostrzewa z Zągot, fotograf Jan Drzewiecki z Płocka i nauczyciel muzyki Maciej Kołodziejski z Płocka.

9 Była to grupa wokalno-teatralna „Będzie Dobrze” z Zespołu Szkół im. Stanisława Staszica w Gąbinie, która działała pod kierunkiem polonistki - Barbary Łukaszewskiej.

10 Były to teksty Moniki Gapińskiej: Rozmowa z Dębem, Oni, Zatęsknię, Kilka słów o Tobie, a także teksty Barbary Wysockiej: Dlaczego, ${ }^{* * * *}$. Wokalne wykonanie wierszy - Joanna Drozdowska, Emilia Dąbrzał, Żaneta Trzaskowska; instrumenty klawiszowe i gitara - Łukasz Stefański; instrumenty perkusyjne - Marcin Czubatka; skrzypce - Przemysław Pasiński. Dużą rolę w reali- 
Innym działaniem edukacyjno-wychowawczym była wycieczka do miejsca narodzin Norwida, czyli do Głuch pod Warszawą, oraz zwiedzanie Muzeum Romantyzmu w Opinogórze. Odbyła się 29 maja 2004 roku i została zorganizowana przez Towarzystwo Naukowe Płockie, powołane do życia w 1820 roku. Grupa uczniów z wychowawcą została zaproszona do udziału w wyjeździe. Bielscy recytatorzy uczcili pamięć o patronie recytacją i śpiewem jego utworów nieopodal dworku, w którym urodził się i spędził wczesne dzieciństwo. Wyjazd do Głuch stanowił kolejny etap wtajemniczania uczniów w świat romantycznego poety po nadaniu jego imienia szkole.

Podsumowując, kampania promująca postać Norwida składała się z dziesięciu działań. Były to: uroczystości Norwidowskie; konkursy literackie, recytatorskie, plastyczne; wystawy; ścienne gazetki szkolne; tworzenie i prezentowanie własnej twórczości; udział w programach artystycznych poza szkołą; powołanie kawiarenki literackiej w szkole; zarejestrowanie wydarzeń na filmach video ${ }^{11}$; nagranie płyty kompaktowej z wierszami gimnazjalistów; publikacje prasowe na temat bieżących wydarzeń oraz program w lokalnej telewizji i audycje radiowe.

W kwietniu 2003 roku w głosowaniu tajnym rodzice, gimnazjaliści i nauczyciele dużą przewagą głosów wybrali C.K. Norwida na patrona szkoły. Rok później Rada Gminy Bielsk nadała uchwałą imię szkole. Społeczność szkolna wyraźnie opowiedziała się za Norwidem, znacznie mniejsze poparcie otrzymali pozostali kandydaci rekomendowani na patrona szkoły ${ }^{12}$. Praca dydaktyczno-wychowawcza wokół promowania postaci i twórczości Norwida okazała się sukcesem i wkroczyła w kolejny etap. Poeta, uznawany za trudnego w odbiorze, zadomowił się w świadomości środowiska szkolnego i otoczenia szkoły. Spójne działania edukacyjno-wychowawcze stały się „ważkim ruchem umysłowym w lokalnej społeczności”"13.

zacji tego zadania odegrał Gminny Ośrodek Kultury w Bielsku w okresie zarządzania nim przez dyrektor Bożenę Majewską.

11 Rok Norwida w Bielsku oraz Poeci w gimnazjum - można je było wypożyczyć z miejscowej biblioteki gminnej.

12 Tajne głosowanie rodziców (uczestniczyło 137 osób): Janusz Korczak - 35 głosów, Wacław Niedziałkowski - 2; Wisława Szymborska - 19; Cyprian K. Norwid - 81. Uczniowie (317 osób) odpowiednio: 72, 13, 145 i 50 głosów. Rada Pedagogiczna (24 osoby) odpowiednio: 4, 1, 13 i 3 głosy.

13 Opinia Grzegorza Wiśniewskiego przywołana w książce Wioletty Żórawskiej (2005: 7). 


\section{PRACA WOKÓŁ CYPRIANA KAMILA NORWIDA - PATRONA SZKOŁY (2004-2019)}

Kolejny etap działań edukacyjno-wychowawczych rozpoczął się od dnia nadania imienia szkole w kwietniu 2004 roku i trwał do wygaszenia gimnazjów, czyli do 31 sierpnia 2019 roku. Stanowił on kontynuację podjętych działań, utrwalał zapoczątkowaną tradycję i przyczynił się do zadomowienia twórczości Norwida w środowisku szkoły, w lokalnym jej otoczeniu oraz miał na celu pracę edukacyjno-wychowawczą wokół patrona.

Informacje dotyczące działań wokół patrona umieszczone zostały w programie wychowawczym szkoły oraz w szkolnym systemie oceniania. Przyjęto autorski program pracy wokół Norwida ${ }^{14}$.

W harmonogramie programu znalazły się cykliczne formy pracy: coroczne apele szkolne w rocznicę śmierci Norwida, coroczne Msze św. w rocznicę urodzin poety ${ }^{15}$, konkursy (szkolne, międzyszkolne, powiatowe) literackie, plastyczne i recytatorskie. Uwzględniono wizualną prezentację informacji w formie tablic informacyjnych. Realizowano też wydarzenia okolicznościowe, jak: poświęcenie sztandaru szkoły i odsłonięcie ściennej tablicy z granitu upamiętniającej wizerunek Norwida, koncert środowiskowy. Ponadto dla uczniów i środowiska lokalnego $\mathrm{z}$ otoczenia szkoły organizowano spotkania z autorytetami nauki i kultury. Tym wydarzeniom towarzyszyły publikacje materiałów informacyjnych, poza tym systematycznie informowano otoczenie bliższe i dalsze środowiska szkolnego o różnych uroczystościach. Stałą formą popularyzacji twórczości patrona była oprawa literacka nagród książkowych przyznawanych absolwentom gimnazjum za bardzo dobre wyniki w nauce. Każdego roku uczniowie otrzymywali książkę $\mathrm{z}$ dedykacja - cytatem $\mathrm{z}$ wybranego dzieła poety romantyzmu.

Najczęściej stosowaną metodą w pracy z uczniami wokół Norwida był projekt edukacyjny (zob. przykłady projektów edukacyjnych zrealizowanych w Gimnazjum im. Cypriana Kamila Norwida w Bielsku w latach 2011-2016: Żórawska 2011: 51-57; Norwidpasjonaci.pl 2016c, 2016d, 2017b). Metoda ta bazuje na opracowanym i przyjętym do realizacji harmonogramie działań oraz na etapowym rozliczaniu uczniów z zadań. Sprawdziła się najlepiej w realizacji uroczystych corocznych obchodów rocznicy śmierci autora Czarnych kwiatów. Realizowano je na podstawie scenariuszy, w których tworzeniu uczestniczyli

14 Uchwałą Rady Pedagogicznej zatwierdzono program na lata 2008-2013 (Norwidpasjonaci.pl 2008).

15 Tradycja Mszy św. w kościele parafialnym w Bielsku rozpoczęła się w 2006 roku i trwała do września 2018 roku (Norwidpasjonaci.pl 2014a, 2015b, 2016a, 2017a, 2018). 
uzdolnieni i zaangażowani uczniowie z grupy projektowej. Czytanie tekstów Norwida odbywało się w formie warsztatów w kilkuosobowych zespołach uczniów w roli badaczy pod kierunkiem polonistki i obejmowało działanie w grupach, wykonywanie ćwiczeń na kartach pracy oraz uwzględnianie różnych warstw dzieła, takich jak: język, konstrukcja utworu, wersyfikacja, a także wymowa i symbolika. Doszukiwano się sensu, przywołując różnorodne konteksty interpretacyjne: biograficzny, historyczny, kulturowy, religijny, filozoficzny. Sięgano do opracowań interpretacji norwidologicznych (Chlebowska i Chlebowski 2008; Chojak i Teleżyńska red. 1991; Makowski red. 1986) oraz korzystano z witryn internetowych poświęconych poecie. Do interpretacji wykorzystywano realizacje wokalne tekstów oraz ich recytację w wykonaniu aktorów ${ }^{16}$. Laureaci konkursów recytatorskich mieli okazję do występowania przed całą społecznością szkolną. Podejmowano próby ilustrowania utworów w formie plakatów, które stanowiły elementy scenografii występów. Organizowano wystawy przybliżające wizerunek poety oraz kalendarium jego twórczości. Uczniowie chętnie realizowali projekty edukacyjne związane z patronem szkoły. Mieli wybór spośród kilku propozycji projektów w zależności od predyspozycji i zainteresowań. Niekiedy sami zgłaszali propozycje realizacji Norwidowskiego projektu edukacyjnego.

Szkolne prezentacje twórczości i biografii autora Vade-mecum wykonywane były w zespołach projektowych. Uzdolniona plastycznie i literacko młodzież każdego roku tworzyła czasową ekspozycję wprowadzającą społeczność szkoły do tematyki prezentowanych na uroczystości utworów poety. Młodzież tworzyła ciekawe tablice ścienne dotyczące pracy wokół Norwida w Bielsku. Pierwsza z nich nosiła tytuł "Cyprian Norwid w naszym gimnazjum 2004-2012”. Kolejna powstała z inicjatywy uczniów dwa lata później i nosiła tytuł „On i My”. Towarzyszyła ona społeczności szkolnej do czasu wygaszenia gimnazjum. Autorzy tych projektów podjęli trud ukazania dokonań koleżanek i kolegów, którzy już ukończyli naukę w gimnazjum. Ponadto należało systematycznie, skutecznie i ciekawie przybliżać biografię patrona oraz wybrane fragmenty jego twórczości uczniom klas młodszych. Grupy projektowe gromadziły i opracowywały materiały związane z pracą wokół patrona. Projektowały też układ treści na ściennej tablicy. Te prace projektowe nie tylko pogłębiały wiedzę o patronie szkoły, lecz także motywowały innych uczniów do zainteresowania się postacią poety i do włączenia się do działania. Podnosiły również estetykę korytarza szkolnego.

Inne grupy projektowe zrealizowały projekt „Z Norwidem za pan brat. Program artystyczny”. Praca przebiegała w kilku etapach. Wykonawcy podzielili

16 Poezja śpiewana (Warska 2003; Niemen 1970, 1975). Poezja recytowana w wykonaniu aktorskim. 
się obowiązkami zgodnie z zainteresowaniami, w efekcie czego powstały grupy zadaniowe: grupa recytatorów, zespół muzyczno-wokalny, konferansjerzy, jurorzy, projektanci (dyplomy, karty konkursowe, rekwizyty, emblematy służące ewaluacji - emotikony), sprawozdawcy. Prezentacja projektu miała charakter programu artystycznego połączonego z konkursem wiedzy o liryce Norwida.

Uczniowie zainteresowani pracą $\mathrm{w}$ technologii informacyjno-komunikacyjnej podejmowali się stworzenia prezentacji multimedialnej, każdorazowo ukazującej wybrane problemy twórczości i przybliżającej konkretne dzieła patrona. Kształcili kluczowe kompetencje (TiK), realizując m.in. projekty edukacyjne: „Na ścieżkach życia i w świecie sztuki Cypriana Norwida” (2015) oraz „Norwid poeta kultury i historii” (2017). Te projekty świadczą nie tylko o umiejętnościach posługiwania się technologiami informacyjno-komunikacyjnymi (Norwidpasjonaci.pl 2016g), lecz także o ich przydatności w ciekawej prezentacji wybranych modułów wiedzy o biografii i twórczości autora doby romantyzmu. Tablice wirtualne umieszczano na internetowej stronie Gimnazjum. Cieszyły się one dużym zainteresowaniem.

Spośród projektów edukacyjnych zrealizowanych w Bielsku warto przywołać ten zatytułowany „Norwid poeta kultury i historii”, zrealizowany w rocznicę śmierci poety w 2016 roku (Norwidpasjonaci.pl 2016e).

Jak zawsze punktem wyjścia była praca z dziełami literackimi. Ciągle poszukiwano ciekawych metodycznie możliwości prezentacji tekstów Norwida. Jedną $\mathrm{z}$ nich była teatralizacja utworu. Wnikliwa lektura dzieła Bema pamięci żałobny-rapsod, z uwzględnieniem wielu kontekstów interpretacyjnych (biograficznego, historycznego, kulturowego, historycznoliterackiego), języka dzieła, wersyfikacji i rytmu, wzbudziła bliższe zainteresowanie uczniów tym utworem. Młodzi czytelnicy odkryli m.in. występującą w rapsodzie na cześć bohatera archaizację, czyli stylizację pogrzebu bohatera według rytuału średniowieczno-rycerskiego, pogańskiego i wczesnosłowiańskiego. Ponadto stwierdzili mitologizację postaci generała, czyli przedstawienie zmarłego niczym wielkiego wodza całego plemienia lub wzorowego rycerza średniowiecznego.

Odsłonięcie przed uczniami wielu warstw dzieła i jego walorów artystycznych sprawiło, że wiersz zaprezentowano w kostiumach oraz z rekwizytami przygotowanymi przez uczniów ${ }^{17}$. Podobnie etapami interpretowano tekst Fortepian Szopena, wykorzystany w scenariuszu tej uroczystości. Teatralizacja

17 Był to apel z maja 2016 roku pn. „Norwid poeta kultury i historii”. W pochodzie żałobnym, zgodnie z tekstem wiersza Bema pamięci żałobny-rapsod, maszerowali: chorągiew, pachołki z pochodniami, panny żałobne ze snopami wonnymi, konchami i glinianymi naczyniami, giermkowie z tarczami i toporami (Norwidpasjonaci.pl 2016e). 
$\mathrm{w}$ tym przypadku polegała na ukazaniu zniszczenia instrumentu - symbolu sztuki. W odpowiednim momencie rekwizyt - fortepian - został zrzucony i rozpadł się na oczach widowni.

Szkolny zespół wokalno-artystyczny zasłynął w gimnazjum i w środowisku zewnętrznym z ciekawej realizacji wierszy: Bema pamięci żałobny-rapsod ${ }^{18}$, Moja piosnka [II] oraz W Weronie. Dwa ostatnie utwory w wokalnym wykonaniu młodzieży brzmiały współcześnie i świeżo, podobały się wszystkim. Dzieła te stały się bardzo popularne. Muzykę skomponował nauczyciel na potrzeby zespołu. Chór wykonywał je podczas majowych apeli w rocznicę śmierci autora Promethidiona oraz w trakcie wrześniowych Mszy św. z okazji urodzin poety. Oprawę muzyczną wydarzeń szkolnych stanowiła muzyka zarówno z epoki romantyzmu, jak i współczesna.

Cenne dla uczniów, nauczycieli i mieszkańców miejscowości było spotkanie z autorytetami naukowymi podczas sympozjum pn. „Rozmowy o Norwidzie”19, które odbyło się w Gminnym Ośrodku Kultury w Bielsku z udziałem prof. dr hab. Jadwigi Puzyniny z Pracowni Słownika Języka Cypriana Norwida Uniwersytetu Warszawskiego oraz dr. Tomasza Korpysza z Uniwersytetu Kardynała Stefana Wyszyńskiego - norwidologa i popularyzatora twórczości autora Vade-mecum.

Kolejnym okolicznościowym wydarzeniem była uroczystość podsumowująca dziesięciolecie pracy wokół Norwida w Bielsku ${ }^{20}$ (patronat nad nią objął Instytut Papieża Jana Pawła II w Warszawie). W programie uroczystości zaplanowano Mszę św. dziękczynną za beatyfikację Ojca Świętego Jana Pawła II oraz za duszę Cypriana K. Norwida w 128. rocznicę śmierci. Rozstrzygnięto międzyszkolny konkurs fotograficzny pn. „Obraz słowa Cypriana Norwida i bł. Papieża Jana Pawła II”. Młodzież była włączona w bieżące wydarzenia kulturowe i religijne, które intensywnie przeżywano w Polsce z okazji beatyfikacji Jana Pawła II. Ponadto szkolne przedsięwzięcie zachęcało uczniów do twórczej postawy i uświadamiało im potrzebę uczestniczenia w nieustannie odbywającym się dialogu kulturowym. Uczniowie pod kierunkiem polonistki weszli w rolę badaczy i podjęli się analizy fragmentów wierszy Norwida przywoływanych przez papieża Jana Pawła II w homiliach podczas pielgrzymek do Polski. Konkursowe

18 Dominika Żaczek zaśpiewała wiersz, akompaniując sobie na ukulele (Norwidpasjonaci.pl 2016b).

19 Wydarzenie zostało zorganizowane przez Stowarzyszenie Młodych Poetów w Gimnazjum w Bielsku oraz Mazowiecki Centrum Kultury i Sztuki w Warszawie, które udzieliło również wsparcia finansowego, a odbyło się 24 września 2005 roku (Norwidpasjonaci.pl 2005).

20 Wydarzenie z 23 maja 2011 roku zostało udokumentowane w „Biuletynie Okolicznościowym” wydanym przez Gimnazjum im. Cypriana K. Norwida w Bielsku (Norwidpasjonaci.pl 2001-2011). 
zadanie zmotywowało młodzież do odczytywania fragmentów wierszy poety oraz urywków homilii papieża, które do nich nawiązują.

Zestawy cytatów (słowa Norwida i inspirowane nimi wypowiedzi papieża) stanowiły materiał bazowy do twórczej analizy i wykonania fotografii. Powstały ciekawe prace (zob. Żórawska 2011: 51-57). Wydarzenie adresowane było do całej społeczności szkoły i mieszkańców gminy. Nauczyciele i uczniowie ze sztandarem uczestniczyli w Mszy św., a następnie odbyła się uroczysta akademia w hali sportowej. Dało to okazję do podsumowania pracy, co najlepiej opisują słowa ks. dr. Zdzisława Struzika:

[...] chciałbym zachęcić Grono Pedagogiczne i Uczniów Gimnazjum im. Cypriana Kamila Norwida do kontynuowania dobrych działań twórczych, które miały miejsce w szkole w latach 2001-2011. Niech te inicjatywy artystyczne będą dla Was możliwością odkrywania własnej tożsamości, środkiem porozumienia z drugim człowiekiem i narzędziem rozumnego wpływania na rzeczywistość. („Biuletyn Okolicznościowy" Gimnazjum... 2011: 2)

Okazją do interpretowania twórczości Norwida w kontekście historycznym i kulturowym była 200. rocznica urodzin Fryderyka Chopina (2010). Gimnazjaliści zrealizowali apel szkolny „Bliżej Chopina” ${ }^{21}$. Tym razem ukazano sylwetki dwóch Polaków artystów, którzy przyjaźnili się i szanowali, a ich dzieła są naszym dziedzictwem narodowym i należy je poznawać. W scenariuszu wykorzystano fragmenty utworów Norwida świadczące o przyjaźni i wielkim uznaniu dla twórczości Chopina. Oprawę muzyczną stanowiły utwory Chopina.

Kolejne wyzwanie stanowił koncert środowiskowy „Norwidowi w hołdzie”22 w wykonaniu uczniów gimnazjum i zaproszonych zespołów artystycznych z terenu gminy. Impreza była adresowana do wszystkich uczniów, społeczności gminy oraz zaproszonych gości - przedstawicieli władzy samorządowej i różnych instytucji.

Gimnazjaliści w maju 2014 roku wystąpili w Towarzystwie Naukowym Płockim (TNP). Tym razem grupa młodzieży skorzystała z zaproszenia na prelekcję polonistki i koordynator projektu „Bielski Norwid” zatytułowaną „Jak czytać Norwida? Refleksje na podstawie podręczników licealnych z lat 19212010" (Norwidpasjonaci.pl 2014b, 2014c). Recytowali wówczas następujące

21 Scenariusz „Bliżej Chopina” autorstwa W. Żórawskiej został nagrodzony w konkursie zorganizowanym przez Narodowe Centrum Kultury w 2010 roku.

22 Zdarzenie z 8 marca 2008 roku zostało zarejestrowane na płycie CD oraz opisane na stronie Norwidpasjonaci.pl (2008). 
liryki Norwida: Specjalności, Marionetki, Moja ojczyzna. Pod kierunkiem nauczyciela muzyki Jarosława Miszewskiego zaprezentowano wokalne wykonanie wiersza Moja piosnka [II] z akompaniamentem gitarowym. Kolejne spotkanie grupy młodzieży z Bielska wraz z rodzicami w sali konferencyjnej TNP odbyło się w kwietniu 2016 roku podczas promocji książki dr Wioletty Żórawskiej pt. Szkolne modele recepcji twórczości Cypriana Norwida do 2010 roku, nieco zmienionej rozprawy doktorskiej ${ }^{23}$. W trakcie tego spotkania uczennica Dominika Żaczek zaciekawiła wszystkich oryginalną interpretacją wokalną wiersza Bema pamięci żałobny-rapsod $\mathrm{z}$ własnym akompaniamentem na ukulele. W środowisku TNP zdobyliśmy sympatię, prezentując Norwida, może nie tylko z tego powodu, że nie mieliśmy konkurencji.

Każda Msza św. w kościele parafialnym z okazji rocznicy urodzin patrona w latach 2006-2018 miała wyjątkową oprawę i angażowała młodzież. Zawsze było słowo o Norwidzie oraz informacja przybliżająca wybrany utwór, który był wykonywany wokalnie z akompaniamentem organów lub szkolnego zespołu muzycznego. Msze odbywały się w niedzielne południe, tak aby włączyć społeczeństwo parafii w nasze obchody. Stały się one tradycją i budziły szacunek lokalnej społeczności. Młodzież pod kierunkiem nauczycieli przygotowywała materiały informacyjne zapowiadające wydarzenie lub informujące o jego przebiegu (Norwidpasjonaci.pl 2015a).

Młodzież angażowała się chętnie do twórczej pracy wokół patrona. Od 2009 roku ustanowiono Nagrodę Norwida. Przyznawano ją każdego roku absolwentowi gimnazjum, który osiągnął najlepsze rezultaty w dobrowolnej pracy w związku z twórczością poety polskiego romantyzmu podczas trzech lat nauki (Norwidpasjonaci.pl 2019). Praca wokół patrona służyła także kształtowaniu tożsamości młodzieży. Pomagała młodym dojrzewać do wartości oraz uczyła myślenia o sobie, ojczyźnie i otaczającym świecie.

Nie sposób w tak krótkim tekście omówić szczegółowo wiele działań zrealizowanych w ciągu 18 lat w ramach projektu „Bielski Norwid” (2001-2019), dlatego jedynie skrótowo zasygnalizowano inicjatywy i metody pracy wokół postaci i twórczości autora Vade-mecum.

W osiemnastoletniej pracy wokół patrona szkoły udało się wypracować lokalną tradycję. Ukazano Norwida w wielu odsłonach podczas uroczystości szkolnych. Pogłębiano wiedzę o twórczości, a szczególnie o liryce, poprzez konkursy recytatorskie, plastyczne i fotograficzne. Przybliżano postać autora podczas

23 Rozprawę doktorską pt. Szkolne modele recepcji twórczości Cypriana Norwida w latach 1922-2010 autorka obroniła na Uniwersytecie Kardynała Stefana Wyszyńskiego w dniu 15 kwietnia 2013 roku. 
corocznych Mszy św. z okazji rocznicy urodzin poety, a także w okolicznościowych wydawnictwach rocznicowych w formie biuletynu i folderów. Reforma oświaty, której założeniem była likwidacja gimnazjów, dała asumpt lokalnej władzy samorządowej do zerwania z tą tradycją. Żadna instytucja edukacji i kultury nie podjęła się ochrony lokalnego dziedzictwa wypracowanego w szkole. Dezaprobatę budzi postawa samorządu lokalnego, której skutkiem było przerwanie tradycji i woli kontynuacji działań wokół postaci Cypriana K. Norwida.

W dziesięciolecie nadania imienia szkole, które przypadało w 2014 roku, pojawiła się w gminie inicjatywa obywatelska nazwania imieniem Norwida skweru znajdującego się w centrum miejscowości. Miała ona na celu dalsze umacnianie więzi mieszkańców gminy z wybitnym Mazowszaninem. W uzasadnieniu wniosku powołano się również na aspekt promocji miejsca w regionie. Praca wokół postaci Norwida w gminnej miejscowości na stałe wpisała się w świadomość uczniów i społeczeństwa. Pomysł ten znalazł akceptację środowiska nauczycieli gimnazjum oraz mieszkańców gminy ${ }^{24}$. Pojawiły się problemy wynikające z wad ludzkiego charakteru oraz z niepotrzebnego upolitycznienia sprawy. Sprzeciw ujawniał się podczas obrad Rady Gminy w okresie od czerwca 2014 roku do czerwca 2015 roku. Trzykrotnie radni zgłaszali wniosek o wprowadzenie punktu nazwania imieniem Norwida skweru w Bielsku, ale nie wprowadzono tej sprawy do porządku obrad ${ }^{25}$. W dniu 1 czerwca 2015 roku projekt uchwały odrzucono większością głosów ${ }^{26}$. Norwid po raz pierwszy w akcie tworzenia prawa lokalnego spotkał się w Bielsku z brakiem akceptacji samorządu po 10 latach skutecznej pracy dydaktyczno-wychowawczej prowadzonej w szkole. Po zamknięciu Gimnazjum w sierpniu 2019 roku ze względów formalnych zakończył się patronat. Nie powstała alternatywna inicjatywa, która mogłaby zastąpić to, co zostało zbudowane.

Filip Niedbała, absolwent Gimnazjum im. Cypriana Kamila Norwida w Bielsku i laureat Nagrody Norwida ostatniej edycji z roku 2019, wyszedł z inicjatywą stworzenia strony internetowej utrwalającej dokonania projektu „Bielski Norwid” z lat 2001-2019, w efekcie której powstała strona o szkolnej recepcji twórczości Cypriana K. Norwida: www.norwidpasjonaci.pl. Zapoczątkowało to nowe otwarcie na Norwida szkolnego, co pozwala mieć nadzieję nie tylko na kontynuację lokalnej

24 Pod wnioskiem podpisało się 258 mieszkańców.

25 Trzy nieudane próby wprowadzenia do porządku obrad sprawy nazwania parku imieniem Cypriana K. Norwida miały miejsce w czerwcu, we wrześniu i w październiku 2014 roku. Głosowanie projektu uchwały odbyło się 1 czerwca 2015 roku.

26 Podczas głosowania dwóch radnych głosowało za przyjęciem, jeden się wstrzymał, a pozostali radni byli przeciw. Nie podano uzasadnienia odrzucenia projektu uchwały (Norwidpasjonaci.pl 2004). 
tradycji w przestrzeni wirtualnej, ale również na inspirowanie innych do podejmowania w edukacji dorobku Norwida, popularyzowania form pracy dydaktyczno-wychowawczej w środowisku szkolnym. Witryna może stanowić przestrzeń dialogu, wymiany wiedzy i doświadczeń w szeroko rozumianej szkolnej recepcji Norwida. Oficjalnie uruchomiona została w listopadzie 2019 roku. Jej prezentacja nastąpiła w Towarzystwie Naukowym Płockim podczas odczytu ukazującego projekt „Bielski Norwid” (2001-2019). Strona internetowa upowszechnia dokonania Gimnazjum związane z patronem (zakładka „Bielski Norwid”). Z kolei zakładka „Wydarzenia: nauka/kultura" utrwala spotkania z autorytetami nauki w Bielsku oraz wykłady w Towarzystwie Naukowym Płockim. Znajdują się tu recenzje spektakli na podstawie twórczości Norwida, które zrealizowano już po zakończeniu projektu „Bielski Norwid”. W zakładce „Norwid nam bliski” jest miejsce na uwagi dotyczące odbioru dzieł Norwida - na refleksje czytelnicze i dyskusje. Zakładka „Multimedia” dokumentuje obraz i dźwięk ukazanych wydarzeń. Strona internetowa poświęcona szkolnej recepcji twórczości Norwida ma na celu stworzenie przestrzeni dialogu ze wszystkimi podmiotami, które zajmują się problematyką szkolnego odbioru tego autora. To zaproszenie do aktywności osób, które nie będąc badaczami dzieł Norwida, sięgają do tej twórczości i odnajdują w niej bliskie sobie wartości, odkrywają w niej cenne myśli o świecie i odnoszą je do siebie. Należy docenić przejrzysty i ciekawy układ treści oraz dbałość o estetykę witryny.

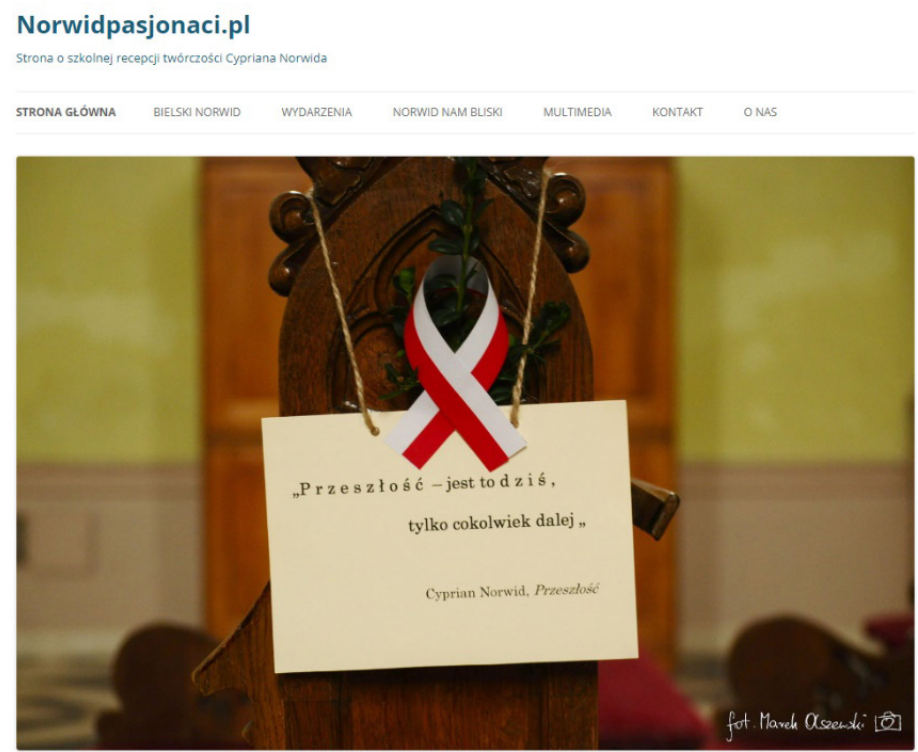

Ryc. 1. Strona www.norwidpasjonaci.pl (fot. Filip Niedbała) 
Pracę wokół Norwida w szkole, realizowaną cyklicznie w dłuższym okresie, należy uznać za niezwykle cenną edukacyjnie i wychowawczo. Z pewnością skłania do poszukiwań ciekawych rozwiązań metodycznych oraz doboru środków dydaktycznych. Norwid może być zadomowiony w szkole wbrew stereotypom o trudności w czytaniu jego dzieł. Kluczem do sukcesu jest m.in. praca metodą projektu edukacyjnego, zastosowanie technologii informacyjno-komunikacyjnej, wdrażanie pomysłów uczniów, stworzenie im warunków do pracy twórczej. Obecność Norwida w szkole i w środowisku lokalnym zależy od zaangażowania nauczycieli, uczniów i otoczenia instytucji w to działanie. Nie ma jednego wzoru dla realizacji zadania pogłębionego czytania i obcowania z twórczością Norwida. Dlatego warto poznawać dokonania innych szkół i instytucji w tym zakresie, aby twórczo się inspirować. W Polsce funkcjonują 22 szkoły średnie (głównie licea) noszące imię Norwida. Każda z nich wypracowała na przestrzeni lat własny model pracy wokół patrona. Stworzenie przestrzeni porozumiewania się między tymi szkołami mogłoby być inspirujące dla szkolnej recepcji twórczości poety. Dokonanie naukowego opisu osiągnięć szkół Norwidowskich jest ważnym zadaniem, szczególnie wobec braku systematycznie prowadzonych badań recepcji szkolnej tego autora. Strona www.norwidpasjonaci.pl może stać się płaszczyzną kontaktu i wymiany doświadczeń edukacyjno-wychowawczych.

Duże znaczenie dla sprawy szkolnego Norwida ma samorząd lokalny, najczęściej organ prowadzący szkołę. Dobrze, jeśli władza lokalna udziela wsparcia oraz gdy angażują się inne regionalne i ogólnopolskie instytucje kultury. Wizerunkowo zyskują także szkoła, gmina i region. Inwestowanie w kształcenie regionalne oraz budowanie więzi społecznych wokół autorytetów i zasłużonych postaci jest kierunkiem potrzebnym w budowaniu tzw. małych ojczyzn, a ten obszar powinien być priorytetem dla samorządów lokalnych.

\section{BIBLIOGRAFIA}

\section{Literatura}

„Biuletyn Okolicznościowy” Gimnazjum im. Cypriana Kamila Norwida. (2011). Bielsk. Bodusz, M. (2009-2010). Cyprian Norwid w rytmach rockowych. Studia Norwidiana, t. 27-28, 101-114.

Cedro, A., Chlebowski, P., Fert, J. (oprac.)., Buś, M., Leociak, J. (współpr.). (2001). Bibliografia interpretacji wierszy Cypriana Norwida. Lublin: Zakład Badań nad Twórczością Cypriana Norwida KUL.

Chlebowska, E., Chlebowski, P. (oprac.). (2008). Norwid. Znaki na papierze: utwory literackie, akwarele, grafiki, rysunki i szkice. Olszanica-Warszawa: Wydawnictwo Bosz, Biblioteka Narodowa. 
Chlebowski, P. (2009-2010). Bema pamięci żałobny-rapsod. Rockowa siuta Niemena do wiersza Norwida. Studia Norwidiana, t. 27-28, 77-100.

Chojak, J., Teleżyńska, E. (red.). (1991). Czemu i jak czytamy Norwida. Warszawa: Wydawnictwa Uniwersytetu Warszawskiego.

Dobiech, J. (2004). Metody pracy na lekcjach zaproponowane w konspektach. W: R. Doktór (red.), Cyprian Norwid w nowej szkole (s. 319-322). Lublin: Norbertinum.

Gajda, K. (2002). RoCK Norwidowski, czyli Cyprian Kamil Norwid tekściarzem. Polonistyka, nr 1, 21-27.

Katechizm Kościoła Katolickiego 1994, nr 1776.

Kulczycka, J., Straszewska, M. (1990). Literatura polska. Romantyzm. Pozytywizm. Warszawa: PWN.

Makowski, S. (red.). (1986). Cypriana Norwida ksztatt prawdy i miłości. Analizy i interpretacje. Warszawa: WSiP.

Niemen, C. (1970). Bema pamięci żałobny-rapsod.

Niemen, C. (1975). Pielgrzym.

Norwidpasjonaci.pl (2001). Rok Norwidowski (2001) w Bielsku. Pobrane z: http://norwidpasjonaci.pl/index.php/wydarzenia-2/nauka/zakladka-bez-nazwy [dostęp: 30.01.2020].

Norwidpasjonaci.pl (2001-2011). Norwid $w$ gimnazjum 2001-2011. Pobrane z: http:// norwidpasjonaci.pl/index.php/bielski-norwid/apele-szkolne/norwid-w-gimnazjum-2001-2011 [dostęp: 30.01.2020].

Norwidpasjonaci.pl (2004). Inicjatywy. Pobrane z: http://norwidpasjonaci.pl/index.php/ bielski-norwid/inicjatywy [dostęp: 30.01.2020].

Norwidpasjonaci.pl (2005). Rozmowy o Norwidzie. Ojczyzna - Praca - Piękno w Bielsku, 24 września 2005 r. Pobrane z: http://norwidpasjonaci.pl/index.php/wydarzenia-2/ nauka/rozmowy-o-norwidzie-ojczyzna-praca-piekno-24-wrzesnia-2005-r [dostęp: 30.01.2020].

Norwidpasjonaci.pl (2008). Pięcioletni program. Pobrane z: http://norwidpasjonaci.pl/index. php/bielski-norwid/publikacje/piecioletni-program [dostęp: 30.01.2020].

Norwidpasjonaci.pl (2014a). 10. rocznica nadania imienia gimnazjum. Pobrane z: http:// norwidpasjonaci.pl/index.php/bielski-norwid/msze-swiete/10-rocznica-nadania-imienia-gimnazjum [dostęp: 30.01.2020].

Norwidpasjonaci.pl (2014b). Szkolne czytanie Norwida - TNP. Pobrane z: http://norwidpasjonaci.pl/index.php/multimedia/szkolne-czytanie-norwida-tnp-2014/. Wersja mówiona [dostęp: 5.03.2020].

Norwidpasjonaci.pl (2014c). Szkolne czytanie Norwida - TNP. Pobrane z: http://norwidpasjonaci.pl/index.php/wydarzenia-2/nauka/odczyt-w-towarzystwie-naukowym-plockim-29-v-2014-r [dostęp: 5.03.2020].

Norwidpasjonaci.pl (2015a). Ulotka. Pobrane z: http://norwidpasjonaci.pl/index.php/bielski-norwid/publikacje/ulotka [dostęp: 6.03.2020].

Norwidpasjonaci.pl (2015b). W 194. rocznice urodzin patrona. Pobrane z: http://norwidpasjonaci.pl/index.php/bielski-norwid/msze-swiete/w-194-rocznice-urodzin-patrona [dostęp: 30.01.2020].

Norwidpasjonaci.pl (2016a). 195. rocznica urodzin C.K. Norwida. Pobrane z: http://norwidpasjonaci.pl/index.php/bielski-norwid/msze-swiete/195-rocznica-urodzin-c-k-norwida [dostęp: 30.01.2020]. 
Norwidpasjonaci.pl (2016b). Dominika Żaczek - „Bema pamięci żałobny-rapsod”. Pobrane z: http://norwidpasjonaci.pl/index.php/multimedia/dominika-zaczek-bema-pamieci -zalobny-rapsod [dostęp: 30.01.2020].

Norwidpasjonaci.pl (2016c). Ilustracje do lektur gimnazjalnych. Pobrane z: http://norwidpasjonaci.pl/index.php/bielski-norwid/projekty-edukacyjne/ilustracje-do-lektur-gimnazjalnych [dostęp: 30.01.2020].

Norwidpasjonaci.pl (2016d). On i my. Pobrane z: http://norwidpasjonaci.pl/index.php/ bielski-norwid/projekty-edukacyjne/on-i-my [dostęp: 30.01.2020].

Norwidpasjonaci.pl (2016e). Poeta kultury $i$ historii. Pobrane z: http://norwidpasjonaci.pl/index.php/bielski-norwid/apele-szkolne/poeta-kultury-i-historii-2016 [dostęp: 30.01.2020].

Norwidpasjonaci.pl (2016f). Referat dr Katarzyny Olszewskiej. Pobrane z: http://norwidpasjonaci.pl/index.php/wydarzenia-2/nauka/referat-dr-katarzyny-olszewskiej [dostęp: 30.01.2020].

Norwidpasjonaci.pl (2016g). Tablica wirtualna. Pobrane z: http://norwidpasjonaci.pl/index. php/bielski-norwid/tablica-wirtualna [dostęp: 30.01.2020].

Norwidpasjonaci.pl (2017a). 196. rocznica urodzin C. Norwida. Pobrane z: http://norwidpasjonaci.pl/index.php/bielski-norwid/msze-swiete/196-rocznica-urodzin-c-norwida [dostęp: 30.01.2020].

Norwidpasjonaci.pl (2017b). Z Norwidem za pan brat. Pobrane z: http://norwidpasjonaci. $\mathrm{pl} /$ index.php/bielski-norwid/projekty-edukacyjne/z-norwidem-za-pan-brat [dostęp: 30.01.2020].

Norwidpasjonaci.pl (2018). Msza 2018 r. Pobrane z: http://norwidpasjonaci.pl/index.php/ bielski-norwid/msze-swiete/msza-2018r [dostęp: 30.01.2020].

Norwidpasjonaci.pl (2019). Nagroda Norwida. Pobrane z: http://norwidpasjonaci.pl/index. php/bielski-norwid/nagroda-norwida [dostęp: 30.01.2020].

Strawa-Kęsek, E. (2015). Metoda projektu w edukacji polonistycznej. Kraków: TAiWPN Universitas.

Sudolski, Z. (2003). Norwid. Opowieść biograficzna. Warszawa: Ancher.

Warska, W. (2003). W Weronie (sł. C. Norwid, muz. A. Kurylewicz). W: Swiat w stowach i obrazach. Literatura i muzyka dla gimnazjum (płyta A, poz. 19). Warszawa: WSiP.

Żórawska, W. (2005). Bielski Norwid. Bielsk: s.n.

Żórawska, W. (2011). Norwid czytany w gimnazjum. Polonistyka, nr 9, 51-57.

Żórawska, W. (2016a). Oni i wiersze, czyli licealista sam na sam z tekstami Cypriana Norwida. W: E. Jaskółkowa, D. Krzyżyk, B. Nieszporek-Szamburska, M. Wójcik-Dudek (red.), Edukacja polonistyczna jako zobowiq̨zanie. Powszechność i elitarność polonistyki (T. 2; s. 395-402). Katowice: Wydawnictwo Uniwersytetu Śląskiego.

Żórawska, W. (2016b). Przekroczyć nieobecność. Norwid w dwudziestoleciu międzywojennym. W: tejże, Szkolne modele recepcji twórczości Cypriana Norwida do 2010 roku (s. 29-60). Warszawa: Wydawnictwo UKSW.

\section{Akty prawne}

Rozporządzenie Ministra Edukacji Narodowej z dnia 15 lutego 1999 r. w sprawie ramowych planów nauczania w szkołach publicznych (Dz.U. 1999, nr 14, poz. 129). 